\title{
Infection Potential of Pleospora allii and Evaluation of Methods for Reduction of the Overwintering Inoculum of Brown Spot of Pear
}

\author{
Isidre Llorente, Albert Vilardell, and Emilio Montesinos, Institute of Food and Agricultural Technology, CeRTA-
} CIDSAV, University of Girona, Av. Lluís Santaló s/n, 17071 Girona (Spain)

\begin{abstract}
Llorente, I., Vilardell, A., and Montesinos, E. 2006. Infection potential of Pleospora allii and evaluation of methods for reduction of the overwintering inoculum of brown spot of pear. Plant Dis. 90:1511-1516.

The capacity for germination and pathogenicity to pear leaves of ascospores of Pleospora allii, the teleomorph of Stemphylium vesicarium, causal agent of brown spot of pear, were studied in vitro. Most ascospores germinated within $1 \mathrm{~h}$ at temperatures between 15 and $20^{\circ} \mathrm{C}$, and the optimum temperature for germination was $18.9^{\circ} \mathrm{C}$. Infections developed on wounded and nonwounded detached pear leaves, but were more frequent on wounded leaves. The minimum infective dose was one ascospore per wound. Biological, chemical, and mechanical methods for decreasing overwintering inoculum of $P$. allii were evaluated. Ascospores were discharged from March to May, depending on the orchard and year. Leaf shredding or removal were the most effective methods of reducing overwintering inoculum. Biological control methods based on application of Thichoderma sp. formulations were partially effective. Chemical methods based on copper and urea treatments were ineffective.
\end{abstract}

Brown spot of pear (Pyrus communis L.), a disease caused by the fungus Stemphylium vesicarium (Wallr.) E. Simmons, produces important economic losses in several fruit-tree-growing areas of Europe, including Spain, Italy, France, Holland, Portugal, and Belgium (2,7,15,27,29). Control of brown spot of pear requires high numbers of fungicide applications during the growing season that can be applied according to a fixed schedule or timed with the BSPcast forecasting system $(17,22)$.

$S$. vesicarium overwinters in the orchard ground on fallen infected leaves and fruit as pseudothecia of its teleomorph Pleospora allii (Rabenh.) Ces. \& De Not. Maturation of pseudothecia depends on temperature, and a cumulative-degree-day model has been evaluated and validated to estimate its development in the field (16). Ascospore discharge from mature pseudothecia takes place mainly from March to May and may constitute the primary inoculum for brown spot (16). However, information is lacking on the capacity of ascospores of $P$. allii to infect pear and on the role of the primary inoculum in the epidemiology of the disease.

Scheduling fungicide sprays with BSPcast provides an average fungicide

\section{Corresponding author: I. Llorente \\ E-mail: isidre.1lorente@udg.es}

Accepted for publication 22 June 2006.

DOI: 10.1094/PD-90-1511

(C) 2006 The American Phytopathological Society savings ranging from 20 to $70 \%$ (17) but has not increased disease control levels compared with the fixed-spray schedule. Also, the efficacy of control is not sufficient under conditions conducive to high disease pressure (high inoculum potential, susceptible cultivars, and warm and wet weather conditions). Therefore, to improve brown spot control, complementary methods oriented to decreasing the inoculum potential are needed. In similar pathosystems such as apple scab, a reduction in the amount of the overwintering inoculum decreased the levels of disease incidence in the subsequent year $(10,32)$. It is expected that better knowledge of the role of $P$. allii in the brown spot disease cycle may provide valuable information for improving control measures removing the overwintering inoculum.

The objectives of the present research were to (i) study the effect of temperature on germination of ascospores of $P$. allii, (ii) determine the capacity of $P$. allii ascospores to infect pear, and (iii) evaluate methods to decrease the overwintering inoculum and limit ascospore discharge.

\section{MATERIALS AND METHODS}

Production of pseudothecia under controlled-environment conditions. $S$. vesicarium strain EPS26, originally isolated from an infected pear, was used for production of pseudothecia of $P$. allii. Cultures of $S$. vesicarium were grown on $\mathrm{V} 8$ agar at $20^{\circ} \mathrm{C}$ under a daily photoperiod of $16 \mathrm{~h}$ of fluorescent light at $150 \mu \mathrm{E} \mathrm{m}^{-2} \mathrm{~s}^{-1}$. The pseudothecia were observed at 2 to 3 weeks after inoculation as small black dots inside the agar medium that contained pseudoparaphyses filling the lumen. At this stage, cultures were transferred to $15^{\circ} \mathrm{C}$, high relative humidity $(\mathrm{RH}>98 \%$ ), and darkness to induce maturation of the pseudothecia. To provide high RH inside culture plates, a wet sterile filter paper disk was placed within a piece of fiberglass mesh $(6$ by $6 \mathrm{~cm})$ pasted to the inner side of the petri plate cover. Pseudothecia were observed daily to determine the maturation stage according to a previous scale reported for $P$. allii $(16,28)$. The material was used for further experiments when most of the pseudothecia contained asci with mature ascospores (tabicated and yellow colored).

Effect of temperature on germination of $\boldsymbol{P}$. allii. Mature pseudothecia of $P$. allii were prepared as described above. In V8 agar, mycelium and conidia of $S$. vesicarium coexisted with pseudothecia of $P$. allii. However, conidia and mycelium developed on the agar surface and pseudothecia grew inside the agar medium. The conidia and mycelium were eliminated by rubbing the agar surface with a sterile cotton swab and gently washing with sterile distilled water (0.05\% Tween 20). Agar pieces were obtained from three different culture plates to ensure a sufficient concentration of ascospores. To break up pseudothecia and release ascospores, the agar pieces were homogenized with a vortex mixer (model MR3000; Kinematica AG, Littau, Switzerland) for $10 \mathrm{~min}$ at $7,000 \mathrm{rpm}$. The ascospore suspension was concentrated by centrifugation at 4,000 rpm for $10 \mathrm{~min}$. Finally, the pellet was resuspended in water agar (1\% agar). Ascospore suspension $(100 \mu \mathrm{l})$ was placed in each of 12 microplate wells and distributed into wells of microplates. The above process was performed at $4^{\circ} \mathrm{C}$ to prevent germination of ascospores. Microplates then were incubated in controlled environment chambers (model 350; Sanyo, Gunma, Japan) at $5,10,15,20,25$, and $30^{\circ} \mathrm{C}$ in complete darkness. Ascospore germination was stopped at $0,30,60,120,180$, and 330 min by adding $10 \mu \mathrm{l}$ of a $4 \%$ formaldehyde solution to each well. The experimental design consisted of one microplate per temperature and two wells per germination time. Ascospore germination was based on 100 ascospores per well, using a light microscope at $\times 100$ or $\times 200$. Ascospores were considered to be germinated if at least one germ tube was longer than or equal to the spore width. Most of the 
spores in the suspension were $P$. allii ascospore, but slight contamination by conidia of $S$. vesicarium was observed. Because conidia and ascospores can be clearly distinguished $(30,31)$, the conidia of $S$. vesicarium were not considered. The experiment was performed three times. The optimum temperature for germination of ascospores was calculated by polynomial regression.

Pathogenicity of $\boldsymbol{P}$. allii ascospores on pear leaves. The pathogenicity of $P$. allii to pear was determined using a detached pear leaf assay (21). Leaves were obtained from micropropagated potted pear plants of cv. Conference (CAV clone; Agromillora Catalana, S.A., Barcelona, Spain).
Inoculations were performed with ascospores obtained from mature pseudothecia as described above. Pseudothecia were transferred from culture plates to a cover slide using fine forceps. Then, under the microscope, the pseudothecial wall was broken upon the addition of $0.2 \mu$ of sterile distilled water and by application of gentle pressure with forceps. The pseudothecia content, including asci, was spread in a thin layer. Released ascospores were transferred with a capillary pipette to leaves in $20 \mu \mathrm{l}$ of water. Inoculation of leaves was performed under a stereoscopic microscope, and care was taken to assure that the inoculum contained only ascospores but no conidia. Two inoculum doses

Table 1. Trials performed for evaluation of different methods to control of Pleospora allii on pear leaf debris

\begin{tabular}{|c|c|c|c|}
\hline Trial, treatments $^{\mathrm{w}}$ & Rate $^{x}$ & Application & Dates of treatment \\
\hline \multicolumn{4}{|l|}{ 1, 1998-1999, Girona } \\
\hline Bordeaux mixture & $2 \mathrm{~g}$ a.i./liter & After leaf fall & 29 October \\
\hline Leaf shredding & $\ldots$ & After leaf fall & 01 December \\
\hline Tricho-1 & $1 \times 10^{6} \mathrm{CFU} / \mathrm{ml}$ & Start of maturation ${ }^{y}$ & $\begin{array}{l}22 \text { January } \\
15 \text { March }\end{array}$ \\
\hline Urea & $5 \%$ & Before leaf fall & 29 October \\
\hline Urea & $5 \%$ & After leaf fall & 27 November \\
\hline Urea & $10 \%$ & Before leaf fall & 29 October \\
\hline \multicolumn{4}{|l|}{ 2, 1999-2000, Girona } \\
\hline Copper oxychloride & $5 \mathrm{~g}$ a.i./liter & After leaf fall & 28 December \\
\hline Leaf shredding & $\ldots$ & After leaf fall & 28 December \\
\hline \multirow[t]{3}{*}{ Tricho-1 } & $1 \times 10^{6} \mathrm{CFU} / \mathrm{ml}$ & Start of maturation & 28 December \\
\hline & $\ldots$ & $\ldots$ & 24 February \\
\hline & $\ldots$ & & $20 \mathrm{March}$ \\
\hline Urea & $5 \%$ & Before leaf fall & 26 October \\
\hline Urea & $5 \%$ & After leaf fall & 26 October \\
\hline \multicolumn{4}{|l|}{ 3, 1999-2000, Girona } \\
\hline Copper oxychloride & $5 \mathrm{~g}$ a.i./liter & After leaf fall & 28 December \\
\hline Leaf shredding & $\ldots$ & After leaf fall & 28 December \\
\hline \multirow[t]{3}{*}{ Tricho-1 } & $1 \times 10^{6} \mathrm{CFU} / \mathrm{ml}$ & Start of maturation & 28 December \\
\hline & $\cdots$ & $\cdots$ & 24 February \\
\hline & & & 20 March \\
\hline Urea & $5 \%$ & Before leaf fall & 26 October \\
\hline Urea & $5 \%$ & After leaf fall & 26 October \\
\hline \multicolumn{4}{|l|}{ 4, 2000-2001, Girona } \\
\hline \multirow[t]{2}{*}{ Tricho-2 } & $3 \times 10^{4} \mathrm{CFU} / \mathrm{ml}$ & Before maturation ${ }^{z}$ & 23 January \\
\hline & & & 19 February \\
\hline \multirow[t]{2}{*}{ Tricho-2 } & $3 \times 10^{4} \mathrm{CFU} / \mathrm{ml}$ & Start of maturation & 19 February \\
\hline & $\ldots$ & $\ldots$ & 06 March \\
\hline Urea & $5 \%$ & After leaf fall & 30 October \\
\hline \multicolumn{4}{|l|}{ 5, 2000-2001, Girona } \\
\hline \multirow[t]{2}{*}{ Tricho-2 } & $3 \times 10^{4} \mathrm{CFU} / \mathrm{ml}$ & Before maturation & 23 January \\
\hline & $\ldots$ & $\ldots$ & 19 February \\
\hline \multirow[t]{2}{*}{ Tricho-2 } & $3 \times 10^{4} \mathrm{CFU} / \mathrm{ml}$ & Start of maturation & 19 February \\
\hline & & & $06 \mathrm{March}$ \\
\hline Urea & $5 \%$ & After leaf fall & 30 October \\
\hline \multicolumn{4}{|l|}{$6,2002-2003$, Selva } \\
\hline Leaf removing & $\ldots$ & After leaf fall & 25 March \\
\hline \multirow{2}{*}{ Tricho-1 } & $1 \times 10^{8} \mathrm{CFU} / \mathrm{ml}$ & Start of maturation & 25 March \\
\hline & $\ldots$ & $\ldots$ & 05 April \\
\hline \multicolumn{4}{|l|}{ 7, 2003-2004, Selva } \\
\hline Leaf removing & $\ldots$ & After leaf fall & 15 December \\
\hline \multirow[t]{2}{*}{ Tricho-1 } & $1 \times 10^{8} \mathrm{CFU} / \mathrm{ml}$ & Start of maturation & 15 March \\
\hline & $\ldots$ & $\ldots$ & 31 March \\
\hline
\end{tabular}

${ }^{\mathrm{w}}$ Trial number, years, and location. Tricho-1 = mixture of different strains of Trichoderma spp. (Trichomic from Trichodex- AMCchemical) and Tricho-2 = Trichoderma harzianum (Inogan S.L.).

${ }^{\mathrm{x}}$ Rates were $300 \mathrm{ml}$ of suspension applied in treatments 1 to 5 and $100 \mathrm{ml}$ of suspension applied in treatments 6 and 7 .

y Applications started when the first mature pseudothecia of $P$. allii were observed and sprays were repeated.

${ }^{\mathrm{z}}$ Applications started before maturation of pseudothecia of $P$. allii was observed and sprays were repeated. of ascospores were used, consisting of 1 and 32 ascospores per inoculation site. A noninoculated control made with sterile distilled water also was included. Inoculation was done on leaves with and without a wound at the inoculation site. For the wounded inoculation, a cut of $5 \mathrm{~mm}$ was made through the leaf with a fine scalpel prior to the application of ascospore inoculum. On each pear leaf, all the combinations of inoculation method (wounded and nonwounded) and ascospore dose (noninoculated, 1, and 32 ascospores) were tested. Inoculated leaves were placed over a sterile wet filter paper in petri dishes and were incubated at $22^{\circ} \mathrm{C}$ with a daily photoperiod of $16 \mathrm{~h}$ of light. Progression of necrotic lesions corresponding to disease symptoms was assessed daily. The experiment was done three times. The experimental design consisted of three replications of each combination of inoculation method per ascospore dose, and each replication was composed of 6 to 10 leaves. A total of 29, 18, and 30 leaves were used for the experimental repetitions. The number of infections produced for each inoculation method and ascospore dose was analyzed with two-factor analysis of variance (ANOVA; Proc GLM, SAS System v.8.00; SAS Institute, Cary, NC). Significant differences $(P=0.0201)$ were found among experiments and, therefore, data were not pooled for ANOVA.

Evaluation of methods for control of $\boldsymbol{P}$. allii on leaf debris. Seven trials were performed under field conditions from 1998 to 2004 at two locations. Number codes are assigned to each trial (Table 1) for their identification throughout this report. Naturally infected pear leaves showing brown spot lesions were collected at early leaf fall stage at the end of October from diseased trees in commercial orchards. In trials 1 to 5,150 to $300 \mathrm{~g}$ of leaves were placed into each fiberglass net bag $(25$ by $25 \mathrm{~cm})$ at the test location. In trials 6 and 7, the amount of leaves was greater and leaves were placed into rectangular devices $(100$ by $50 \mathrm{~cm})$ with lateral wooden walls that were placed on the ground and covered with a fiberglass net, such that the leaves were in direct contact with the soil. The net bags and rectangular devices determined a replicate unit and were placed along the tree rows. The treatments consisted of biological, chemical, and mechanical methods for control of $P$. allii (Table 1). A nontreated control was included in all trials. The treatments were arranged in a completely randomized block design with three replications of one bag or rectangular device.

For biological control, one of two commercial formulations of Trichoderma spp. were used. One product was Trichomic, coded as Tricho-1 (Trichodex-AMC Chemical, Sevilla, Spain), consisting of a liquid formulation composed of a mixture of strains of Trichoderma harzianum and 
T. viride and marketed as a plant growth stimulant. In trials 1 to 3 , the Trichomic treatment suspension contained $1 \times 10^{6}$ $\mathrm{CFU} / \mathrm{ml}$ and $300 \mathrm{ml}$ were applied per net bag. In trials 6 and 7, the suspension contained $1 \times 10^{8} \mathrm{CFU} / \mathrm{ml}$ and $100 \mathrm{ml}$ were sprayed per rectangular device. The second type of biological control treatment was applied to trials 4 and 5 and consisted of TRI003 (Inogan, Lleida, Spain), coded as Tricho-2. TRI003 is a powder formulation of $T$. harzianum and sold as a plant growth stimulant. The treatment was sprayed to each rectangular device as a $300-\mathrm{ml}$ suspension of $3 \times 10^{4} \mathrm{CFU} / \mathrm{ml}$. Tricho- 1 and Tricho- 2 were applied in all trials according to the maturation stage of pseudothecia. The first application of Tricho- 1 and Tricho-2 was performed when the first mature pseudothecium was observed and was repeated according to the schedule shown in Table 1. In trials 4 and 5, an additional treatment was performed consisting of an application before the first mature pseudothecia were detected, with reapplication done 4 weeks later.

For chemical control, copper derivatives were used in trials 1,2 , and 3 . Bordeaux mixture ( $2 \mathrm{~g}$ a.i./liter) was tested in trial 1 and copper oxychloride ( $5 \mathrm{~g}$ a.i./liter) was used in trials 2 and 3, at a rate of $300 \mathrm{ml}$ per net bag. Urea also was tested in trials 1 to 5 as a method to increase nitrogen content in plant tissues and promote leaf degradation. Urea was sprayed as a 5 or $10 \%$ solution (wt/vol) and, in some trials, was applied directly to the trees before leaf fall or after the leaves were collected (Table 1). When urea was applied after leaf fall, the treatments were performed directly on collected leaves at a rate of $300 \mathrm{ml}$ per net bag.

Mechanical methods of control consisted of shredding the leaves with a vortex to obtain small pieces of 0.2 to $0.5 \mathrm{~cm}^{2}$ (trials 1 to 3 ), or completely removing leaves from the soil (trials 6 and 7) (Table 1).

Three to five leaves were removed from the boxes and net bags in the nontreated

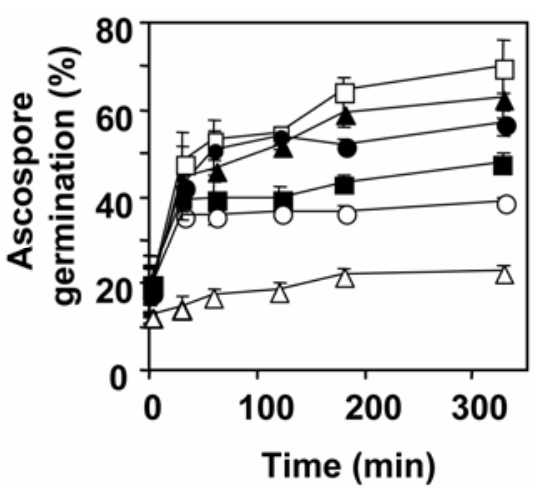

Fig. 1. Germination of ascospores of Pleospora allii on water agar at different temperatures. Temperatures were $5(\Delta), 10(\mathbf{\square}), 15(\mathbf{\Delta}), 20$ $(\square), 25(\bullet)$, and $30^{\circ} \mathrm{C}(\bigcirc)$. Values are the mean of three experiments. Bars correspond to the mean standard error for the three experiments. controls every 7 to 10 days, beginning at the start of field trials, and transported to the laboratory to determine the presence of mature ascospores. Pseudothecia from leaves were selected randomly and transferred to a distilled water drop placed on a glass slide. The pseudothecia were crushed with a coverslip and the maturation stage was determined. When the first asci containing mature ascospores were observed, spore traps were installed in each treatment repetition. Traps consisted of glass slides ( 76 by $26 \mathrm{~mm}$ ) with the underside painted with a silicon solution (Lanzoni S.R.L., Bologna, Italy) that were positioned at 0.5 to $1 \mathrm{~cm}$ above leaves. Glass slides were removed and replaced by new ones every 7 to 10 days. The removed slides were transported to the laboratory and fixed using a jelly solution (Lanzoni S.R.L.). Ascospores were counted microscopically in two longitudinal traverses at $\times 100$ to $\times 200$ and number of ascospores per square centimeter was calculated. In trials 1 to 5 , two slides were used per treatment replication; whereas, in trials 6 and 7, four slides were exposed. The trials ended in June to July when ascospores were no longer observed. Cumulative numbers of ascospores released also were analyzed using the area under the cumulative ascospore progress curve (AUCAC), which was calculated by the midpoint method (4). Due to high variability in observed data, values were transformed to $\log _{10}$ before analysis to stabilize the variance. The effect of treatments on total ascospore discharge and AUCAC was determined by means of ANOVA for a randomized complete block design using the GLM procedure (SAS System v.8.00; SAS Institute). Means comparisons were performed with Fisher's protected least significant difference $(P=0.05)$. Data also were analyzed by contrast analysis and each treatment was compared with the nontreated control.

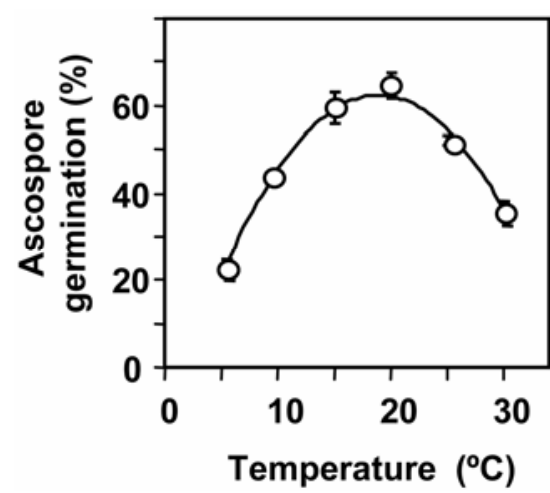

Fig. 2. Effect of temperature on germination of ascospores of Pleospora allii on water agar. Each data point is the mean of three experiments and bars represent standard error. The line corresponds to predictions obtained by fitting data points to $y=-0.212 x^{2}+8.048 x-13.00\left(R^{2}=\right.$ $0.98)$ where $y$ represents percent germination and $x$ is temperature $\left({ }^{\circ} \mathrm{C}\right)$.

\section{RESULTS}

Effect of temperature on germination of $\boldsymbol{P}$. allii. Germination of ascospores in each of the three experiments at each temperature did not differ significantly $(P=$ 0.3135 ) and data were combined (Fig. 1). In all, 10 to $18 \%$ of the ascospores were germinated at the start of incubation. This result was observed consistently for all the experiments. Also, after $5 \mathrm{~h}$ of incubation, about $30 \%$ of ascospores did not germinate. At $10,15,20,25$, and $30^{\circ} \mathrm{C}$, the rate of germination was maximum within the first $30 \mathrm{~min}$. At longer exposure times, the rate of germination decreased. The optimal temperature range for ascospore germination was 15 to $20^{\circ} \mathrm{C}$ (Fig. 2). An analysis of the data using polynomial regression showed that the optimum temperature for germination of $P$. allii was $18.9^{\circ} \mathrm{C}$.

Pathogenicity of $P$. allii ascospores on pear leaves. Ascospores inoculated on wounded leaves produced infections in $79 \%$ of leaves at the minimum dose of one ascospore per wound and in 88 to $93 \%$ when 32 ascospores were inoculated (Fig. $3)$. The frequency of infections in nonwounded leaves was 14 to $57 \%$ when one ascospore was inoculated and 24 to $63 \%$ with 32 ascospores. Necrotic lesions appeared 2 to 3 days after inoculation and developed gradually. Appearance of le-

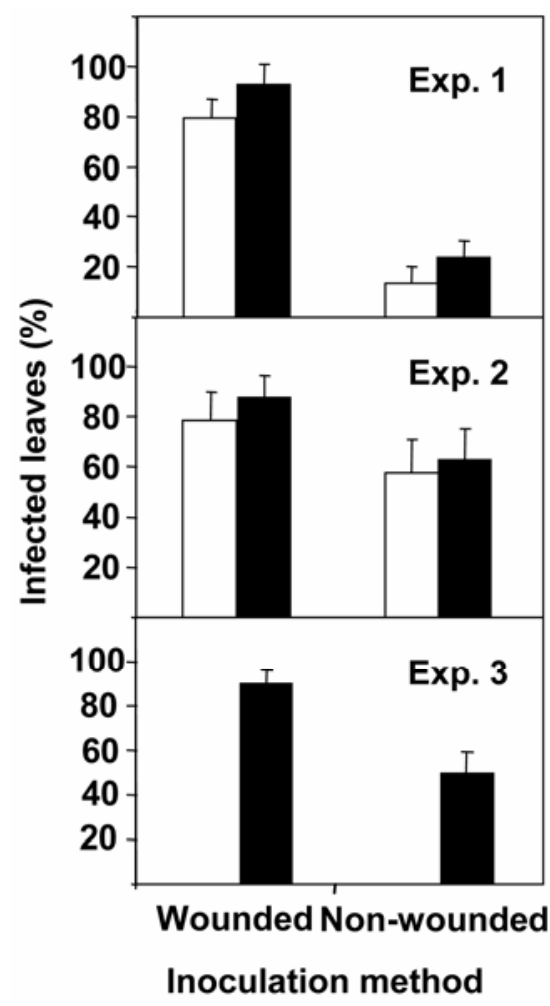

Fig. 3. Infectivity of ascospores of Pleospora allii on detached pear leaves with two spore doses and methods of inoculation. Inoculum doses were 1 ( $\square$ ), and 32 (ロ) ascospores/inoculation site in experiments 1 and 2, and only 32 ascospores/inoculation site in experiment 3. Inoculation methods consisted of wounded or nonwounded leaves. Bars represent the standard error of the mean. 
sions caused by $P$. allii was similar to infections produced by $S$. vesicarium. At the end of the experiment, $S$. vesicarium was recovered from most of the inoculated leaves. No lesions developed in control leaves inoculated with sterile water. The effect of ascospore dose was not significant $(P=0.111$ and 0.529 for experiments 1 and 2, respectively). The effect of inoculation method was significant in experiments 1 and $3(P<0.0001$ and 0.022 , respectively) but not in experiment 2 ( $P=$ $0.124)$, with wounding improving pathogenicity. The interaction of inoculum dose-wound treatments was not significant in any of the three experiments.

Evaluation of methods for control of $P$. allii on leaf debris. The pattern of ascospore release from pear leaf debris was similar in all trials, with substantial release during March to May (Fig. 4). Variability among replicates within each treatment was high. The effect of treatments in ascospore release (Table 2) was significant in trials $1(P=0.0440), 6(P=0.0004)$, and 7
$(P=0.0038)$, but not significant in trials 2 $(P=0.1413), 3(P=0.0600), 4(P=$ $0.2167)$, and $5(P=0.1782)$.

The use of urea at $5 \%$ and the strategy of application (on trees or to leaf debris) had no significant effect on reduction of ascospore levels compared with nontreated control (trials 1 to 4). A similar result was obtained using urea at $10 \%$ in trial 1 . Copper treatments did not reduce the number of trapped ascospores compared with nontreated control (trials 1 to 3 ).

Results with either of the two formulations of Trichoderma spp. were variable. The effect of Tricho-1 was not significant in trials 2, 3, 6, and 7 but was significant in trial 1 when compared with the nontreated control. However, the number of ascospores trapped in four of the five trials (trials 1, 2, 6, and 7) was consistently lower than in the nontreated control (57 to $96 \%$ reduction). The effect of product Tricho-2 did not differ from the control.

Mechanical methods of leaf shredding or removal showed the highest efficacy in reduction of inoculum. The treatments based on leaf shredding (trials 1, 2, and 3) decreased the number of trapped ascospores by 82 to $93 \%$ compared with the nontreated control, but was only significant in trial 1 (Table 2). The removal of leaf and fruit debris (trials 6 and 7) was the most effective method because practically no ascospores were captured from these treatments (Table 2).

When the AUCACs were analyzed, the results were similar to the previously described data using total trapped ascospores per square centimeter (data not shown).

\section{DISCUSSION}

The optimal temperature range for germination of $P$. allii ascospores $\left(15\right.$ to $\left.20^{\circ} \mathrm{C}\right)$ was slightly different from that of conidia of $S$. vesicarium $\left(18\right.$ to $\left.30^{\circ} \mathrm{C}\right)(7,23)$. The optimum temperature in $P$. allii was lower $\left(18.9^{\circ} \mathrm{C}\right)$ than in $S$. vesicarium $\left(23.2^{\circ} \mathrm{C}\right)$ (23). This difference may reflect an adaptation of ascospores to winter or spring conditions with cold temperatures (16),
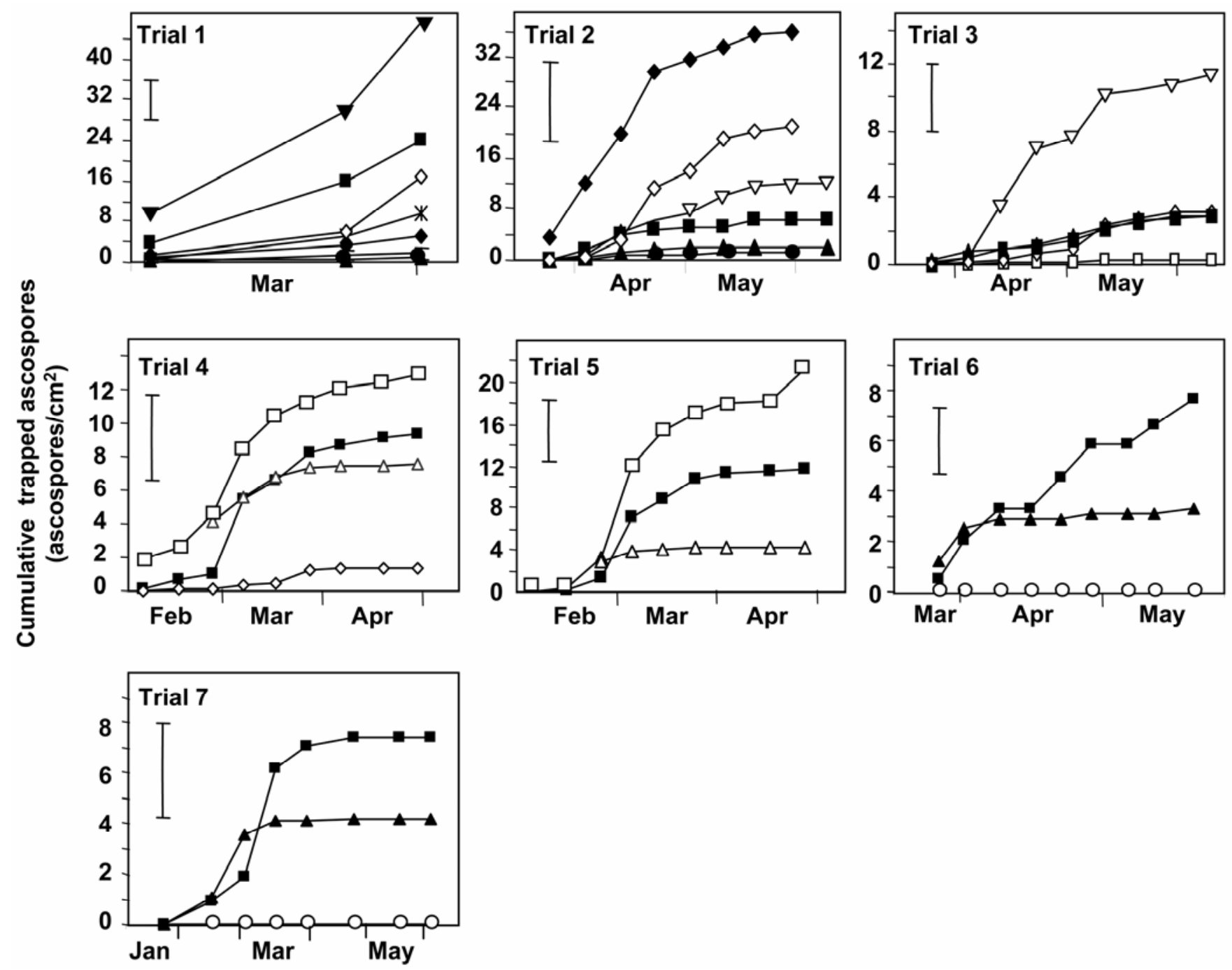

Fig. 4. Effect of treatments of overwintering leaf debris on release of ascospores by Pleospora allii. Panels show accumulated ascospore discharge in field trials 1 through 7. Treatments correspond to Bordeaux mixture $(\nabla)$, copper oxychloride $(\nabla), 5 \%$ urea applied after $(\diamond)$ or before leaf fall $(\diamond), 10 \%$ urea applied before fall $(*)$, Tricho-1 $(\mathbf{\Lambda})$, Tricho-2 applied before $(\square)$ or at start of pseudothecia maturation $(\Delta)$, leaf shredding $(\bullet)$, leaf removing $(\bigcirc)$, and nontreated control ( $\mathbf{\square})$. Bars for each trial correspond to the mean standard error of all treatments. 
contrary to conidia that develop during summer at warmer temperatures $(22,23)$. This may indicate that potential infection capacity during spring will be higher for $P$. allii than for $S$. vesicarium.

Most ascospores germinated within 30 to 60 min of being placed on water agar. The rate of germination observed for ascospores was similar to conidia and, in both cases, was very high compared with other fungi (15). The speed of germination of $P$. allii may explain why a significant amount of ascospores had already germinated at the start of the germination experiments. Maximum germination after $5 \mathrm{~h}$ was $70 \%$, indicating that some ascospores either required a longer time of incubation or failed to germinate. The stage of development of asci was based on the morphology of the ascus contents and ascospore shape and color (16); therefore, it may be that some visually mature ascospores were not physiologically mature. This could explain why, despite using approaches to minimize variability (i.e., same age culture, culture medium, controlled environment, and so on), differences in ascospore maturity in and between asci occurred, which affected germination capacity and contributed to the observed variability. Similar results have been described in other fungi such as Venturia inaequalis and Zygophiala jamaicensis $(11,24)$. Also, other authors reported that germination failure of ascospores was related to suboptimal conditions of temperature and $\mathrm{RH}$ during their production $(3,25)$.

The infectivity of ascospores of $P$. allii on pear leaves was high, and a single ascospore was found to be capable of causing a lesion on a wounded leaf. Also, infections were produced on nonwounded leaves, supporting the hypothesis that the fungus penetrates thorough stomata or directly through the cuticle. Differences observed in the three experiments without wounds may be attributable to a differential susceptibility of leaves.

The high infectivity potential of $P$. allii may be due, in part, to the fact that ascospores are polyspermic, as are conidia of $S$. vesicarium, thus increasing the probability of infection. Additionally, the capacity of $P$. allii to produce lesions from which $S$. vesicarium was recovered reinforces the hypothesis that $P$. allii contributes to the primary inoculum of brown spot and plays an important role in the start of the annual cycle of the disease.

Previous reports studied the dynamics of $P$. allii pseudothecial maturation in the field, and a model relating the proportion of mature pseudothecia to cumulative degree-days has been developed and validated (16). According to this model, ascospores mature from January to May. In the present work, they were released mainly from March to May. Therefore, the first peak of brown spot symptoms often observed in June (17) may be due to infec- tions of susceptible plant tissue developing from April to May during ascospore release. The survival rate of ascospores released before leaves and fruit appear is not known.

Another question regarding the life cycle of brown spot concerns the capacity of conidia of $S$. vesicarium to overwinter and contribute to early epidemics. S. vesicarium may be similar to conidia of $V$. inaequalis that overwinter in the inner bud tissues of apple $(1,13)$, and of Alternaria mali on leaf litter (9).

The saprophytic phase appears to be critical to the survival of $P$. allii and $S$. vesicarium, and disruption of this stage of the pathogen's life cycle may be an efficient control strategy. Several methods have been evaluated herein to reduce the ascosporic inoculum. Unfortunately, variability was high in our study and limited the conclusions. Problems of variability also were reported in $V$. inaequalis, a similar fungus, for pseudothecial production in vitro (26). The high number of field tests and the complex experimental design used in our work prevented implementation of methods used by others to reduce variability $(12,20,32)$.

Application of copper compounds during the autumn or winter did not decrease the number of ascospores of $P$. allii that were trapped. Applications of urea at different doses and timing did not result in reduction of $P$. allii ascospores. Reduction of pseudothecia in leaf litter by urea treatments has been reported by several authors for pathogens such as $V$. inaequalis $(5,18,19)$. Also, applications of urea at rates similar to those used herein reduced ascospore production of Mycosphaerella citri on citrus by $90 \%$ and of $V$. inaequalis on apple up to $97 \%(5,20,32)$. However, most of these previous studies were performed under in vitro conditions or by evaluating leaf disks, whereas the results shown herein were obtained in the field.

Biocontrol using strains of Trichoderma (Tricho-1) showed some efficacy in reducing the number of ascospores trapped. Similar results have been reported using Trichoderma spp. that have reduced production of ascospores of $V$. inaequalis in vitro by more than $83 \%(5,6,26)$. Many Trichoderma spp. achieve biocontrol by complex mechanisms, including production of antibiotics, and enzymes that have been implicated in mycoparasitism or competitive interactions $(8,14)$. The efficacy of Trichoderma spp. also is influenced by the temperature, moisture, and other members of the microbiota that may be present (14). In those studies where a Trichoderma sp. was effective, it usually was incorporated into the soil; however, we applied the treatment at the leaf-soil interface. This application, directed at reduction of inoculum on leaf debris, may negatively affect the activity of Trichoderma spp. because of adverse temperature conditions and water availability at the soil surface.

The mechanical methods of leaf shredding and leaf removal were clearly effective in reducing ascospore release of $P$. allii. Similar results were reported for control of $V$. inaequalis, where the shredding of leaf litter in November and April reduced scab up to $90 \%(32,33)$. Rossi et al. (29) reported that $P$. allii is able to colonize leaf litter of several herbaceous

Table 2. Effect of treatments of pear leaf debris on release of Pleospora allii ascospores in seven trials performed in experimental and commercial orchards

\begin{tabular}{|c|c|}
\hline Trial, treatments & Ascospores $/ \mathrm{cm}^{2 t}$ \\
\hline \multicolumn{2}{|l|}{1} \\
\hline Bordeaux mixture & $47.2 \mathrm{a}$ \\
\hline Leaf shredding & $1.7 \mathrm{~b}$ \\
\hline Nontreated control & $24.1 \mathrm{a}$ \\
\hline Tricho- $1^{\mathrm{u}}$ & $0.7 \mathrm{~b}$ \\
\hline Urea-5-before $^{\mathrm{v}}$ & $4.9 \mathrm{ab}$ \\
\hline Urea-5-afterw & $16.9 \mathrm{ab}$ \\
\hline Urea-10-before ${ }^{\mathrm{x}}$ & $9.4 \mathrm{ab}$ \\
\hline \multicolumn{2}{|l|}{2} \\
\hline Copper oxychloride & $12.2 \mathrm{a}$ \\
\hline Leaf shredding & $1.1 \mathrm{a}$ \\
\hline Nontreated control & $6.2 \mathrm{a}$ \\
\hline Tricho-1 & $2.1 \mathrm{a}$ \\
\hline Urea-5-after & $21.2 \mathrm{a}$ \\
\hline Urea-5-before & $35.8 \mathrm{a}$ \\
\hline \multicolumn{2}{|l|}{3} \\
\hline Copper oxychloride & $11.3 \mathrm{a}$ \\
\hline Leaf shredding & $0.3 \mathrm{a}$ \\
\hline Nontreated control & $2.9 \mathrm{a}$ \\
\hline Tricho-1 & $2.9 \mathrm{a}$ \\
\hline Urea-5-after & $3.2 \mathrm{a}$ \\
\hline \multicolumn{2}{|l|}{4} \\
\hline Nontreated control & $9.3 \mathrm{a}$ \\
\hline Tricho- $2^{y}$ & $12.9 \mathrm{a}$ \\
\hline Tricho- $2^{z}$ & $7.5 \mathrm{a}$ \\
\hline Urea-5-after & $1.4 \mathrm{a}$ \\
\hline \multicolumn{2}{|l|}{5} \\
\hline Nontreated control & $11.8 \mathrm{a}$ \\
\hline Tricho- $2^{y}$ & $21.3 \mathrm{a}$ \\
\hline Tricho- $2^{\mathrm{z}}$ & $4.8 \mathrm{a}$ \\
\hline \multicolumn{2}{|l|}{6} \\
\hline Leaf removing & $0 \mathrm{~b}$ \\
\hline Nontreated control & $7.7 \mathrm{a}$ \\
\hline Tricho-1 & $3.3 \mathrm{a}$ \\
\hline \multicolumn{2}{|l|}{7} \\
\hline Leaf removing & $0.1 \mathrm{~b}$ \\
\hline Nontreated control & $7.5 \mathrm{a}$ \\
\hline Tricho-1 & $4.2 \mathrm{a}$ \\
\hline
\end{tabular}

${ }^{t}$ Mean of total ascospores counted for each treatment and repetition in all trials divided by surface sampled. Values followed by the same letter are not significantly different $(P=0.05)$ according to Fisher's protected least significant difference. Statistical analysis was performed using $\log _{10}$-transformed data.

u Mixture of different strains of Trichoderma sp. (Trichomic from Trichodex- AMCchemical). Applications started when the first mature pseudothecia of $P$. allii were observed.

$\checkmark$ Urea applied at 5\% (before leaf fall).

${ }^{\mathrm{w}}$ Urea applied at 5\% (after leaf fall).

${ }^{x}$ Urea applied at $10 \%$ (before leaf fall).

y Trichoderma harzianum (Inogan S.L.). Applications started before maturation of pseudothecia of $P$. allii was observed.

${ }^{\mathrm{z}} T$. harzianum (Inogan S.L.). Applications started when the first mature pseudothecia of P. allii were observed. 
plants commonly formed in orchards, thus reinforcing the importance of mechanical methods to prevent overwintering of pseudothecia in the orchard floor. In spite of that, it is necessary to quantify the contribution to the primary inoculum of dead herbaceous plants covering the soil of pear orchards; it is expected that removing this material together, with the leaves and fruit of pear, will maximize ascospore reduction.

Due to the lack of statistical significance of some treatments in several trials, it will be necessary to do more experiments to confirm the trend observed in control of primary inoculum using Trichoderma spp., as well as the effect of sanitation practices on disease progress during the subsequent vegetative period. Based on the studies herein, control of $P$. allii should be focused on sanitation practices consisting of removal of leaf and fruit litter from the orchard floor in autumn. Sanitation could be supplemented with the early application of effective Trichoderma strains from February to March when the first mature pseudothecia are observed. These measures can reduce inoculum potential and may result in more effective disease control during the vegetative period than using only fungicide treatments scheduled according BSPcast.

The results reported here provide increased knowledge of the biology of $P$. allii. This information is being coupled to the model for prediction of maturation of pseudothecia of $P$. allii and to the BSPcast forecasting system developed for scheduling fungicides for control of $S$. vesicarium. An integrated brown spot management system is under development and field evaluation.

\section{ACKNOWLEDGMENTS}

This research was supported in part by grants from Instituto Nacional de Investigaciones Agrarias (SC99-055 and RTA03-056), Subdirección General de Cooperación Internacional (Hi2003-0358) of Spain, and Comissió Interdepartamental de Recerca i Tecnologia of the Generalitat de Catalunya. We thank the Mas Badia Agricultural Experiment Station and P. Vilardell, J. Arnal, B. Ferrer, and D. Parron for helpful assistance.

\section{LITERATURE CITED}

1. Becker, C. M., Burr T. J., and Smith, C. A. 1992. Overwintering of conidia of Venturia inaequalis in apple buds in New York orchards. Plant Dis. 76:121-126.

2. Blancard, D., Allard, E., and Brest, P. 1989. La Stemphyliose du poirier ou "macules brunes." Phytoma 406:37-38.

3. Caesar, A. J., and Pearson, R. C. 1983. Envi- ronmental factors affecting survival of ascospores of Sclerotinia sclerotiorum. Phytopathology 73:1024-1030.

4. Campbell, C. L., and Madden, L. V. 1990. Introduction to Plant Disease Epidemiology. John Wiley and Sons, New York.

5. Carisse, O., Philion, V., Rolland, D., and Bernier, J. 2000. Effect of fall application of fungal antagonists on spring ascospore production of the apple scab pathogen, Venturia inaequalis. Phytopathology 90:31-37.

6. Carisse, O., and Rolland, D. 2004. Effect of timing of application of the biological control agent Microsphaeropsis ochracea on the production and ejection pattern of ascospores by Venturia inaequalis. Phytopathology 94:13051314.

7. Cugier, J. P., and Humbert, W. 1991. Stemphyliose du poirier. Etude de la biologie du parasite et recherches des fongicides actifs. Phytoma 431:47-50.

8. Faize, M., Malnoy, M., Dupuis, F., Chevalier, M., Parisi, L., and Chevreau, E. 2003. Chitinases of Trichoderma atroviride induce scab resistance and some metabolic changes in two cultivars of apple. Phytopathology 93:14961504.

9. Filajdic, N., and Sutton, T. B. 1995. Overwintering of Alternaria mali, the causal agent of Alternaria blotch of apple. Plant Dis. 79:695698.

10. Gadoury, D. M., and MacHardy, W. E. 1986. Forecasting ascospore dose of Venturia inaequalis in commercial apple orchards. Phytopathology 76:112-118.

11. Gadoury, D. M., Seem, R. C., Rosenberger, D. A., MacHardy, W. E. ,and Berkett, L. P. 1992. Disparity between morphological maturity of ascospores and physiological maturity of asci in Venturia inaequalis. Plant Dis. 76:277-282.

12. Gadoury, D. M., Stensvand, A., and Seem, R. C. 1996. A wind tunnel for controlledenvironment studies of ascospore release by Venturia inaequalis. Phytopathology 86:596601.

13. Holb, I. J., Heijne, B., and Jeger, M. J. 2004. Overwintering of conidia of Venturia inaequalis and the contribution to early epidemics of apple scab. Plant Dis. 88:751-757.

14. Howel, C. G. 2003. Mechanisms employed by Trichoderma species in the biological control of plant diseases: The history and evolution of current concepts. Plant Dis. 87:4-10

15. Llorente, I., and Montesinos, E. 2002. Effect of relative humidity and interrupted wetness periods on brown spot severity of pear caused by Stemphylium vesicarium. Phytopathology 92:99-104.

16. Llorente, I., and Montesinos, E. 2004. Development and field evaluation of a model to estimate the maturity of pseudothecia of Pleospora allii on pear. Plant Dis. 88:215-219.

17. Llorente, I., Vilardell, P., Bugiani, R., Gherardi, I., and Montesinos, E. 2000. Evaluation of BSPcast disease warning system in reduced fungicide use programs for management of brown spot of pear. Plant Dis. 84:631-637.

18. MacHardy, W. E. 1996. Apple Scab Biology, Epidemiology, and Management. American Phytopathological Society Press, St. Paul, MN.
19. MacHardy, W. E., Gadoury, D. M., and Gessler, C. 2001. Parasitic and biological fitness of Venturia inaequalis: Relationship to disease management strategies. Plant Dis. 85:1036-1051.

20. Mondal, S. N., and Timmer, L. W. 2003. Effect of urea, $\mathrm{CaCO}_{3}$, and dolomite on pseudothecial development and ascospore production of $M y$ cosphaerella citri. Plant Dis. 87:478-483.

21. Montesinos, E., Bonaterra, A., Ophir, Y., and Beer, S. V. 1996. Antagonism of selected bacterial strains to Stemphylium vesicarium and biological control of brown spot of pear under controlled environment conditions. Phytopathology 86:856-863.

22. Montesinos, E., Moragrega, C., Llorente, I., Vilardell, P., Bonaterra, A., Ponti, I., Bugiani, R., Cavanni, P., and Brunelli, A. 1995. Development and evaluation of an infection model for Stemphylium vesicarium on pear based on temperature and wetness duration. Phytopathology 85:586-592.

23. Montesinos, E., and Vilardell, P. 1992. Evaluation of Fast as a forecasting system for scheduling fungicide sprays for control of Stemphylium vesicarium on pear. Plant Dis. 76:1221-1226.

24. Ocamb-Basu, C. M., and Sutton, T. B. 1988. Effects of temperature and relative-humidity on germination, growth, and sporulation of $Z y$ gophiala jamaicensis. Phytopathology 78:100103.

25. Owens, O. V. H., and Krizek, D. T. 1980 Multiple effects of UV-radiation (265-330 nm) on fungal spore emergence. Photochem. Photobiol. 32:41-49.

26. Philion, V., Carisse, O., and Paulitz, T 1997. In vitro evaluation of fungal isolates for their ability to influence leaf rheology, production of pseudothecia, and ascospores of Venturia inaequalis. Eur. J. Plant Pathol. 103:441-452.

27. Ponti, I., Cavanni, P., and Brunelli, A. 1982. "Maculatura bruna" delle pere: eziologia e difesa. Inf. Fitopatol. 3:35-40.

28. Prados-Ligero, A. M., González-Andújar, J. L., Melero-Vara, J. M., and Basallote-Ureba, M. J. 1998. Development of Pleospora allii on garlic debris infected by Stemphylium vesicarium. Eur. J. Plant Pathol. 194:861-870.

29. Rossi, V., Pattori, E., Giosue, S., and Bugiani, R. 2005. Growth and sporulation of Stemphylium vesicarium, the causal agent of brown spot of pear, on herb plants of orchard lawns. Eur. J. Plant Pathol. 111:361-370.

30. Simmons, E. G. 1969. Perfect states of Stemphylium. Mycologia 61:1-26.

31. Simmons, E. G. 1985. Perfect states of Stemphylium. II. Sydowia Ann. Mycol. Ser. II 38:284-293.

32. Sutton, D. K., MacHardy, W. E., and Lord, W. G. 2000. Effects of shredding or treating apple leaf litter with urea on ascospore dose of Venturia inaequalis and disease buildup. Plant Dis. 84:1319-1326.

33. Vincent, C., Rancourt, B., and Carisse, O. 2004. Apple leaf shredding as a non-chemical tool to manage apple scab and spotted tentiform leafminer. Agric. Ecosyst. Environ. 104:595-604 